\title{
Penicillinase producing strains of Neisseria gonorrhoeae in the West Midlands 1979-83
}

\author{
J C CLAY \\ From the General Hospital, Birminghain
}

SUMMARY All cases of gonorrhoea caused by penicillinase producing strains of Neisseria gonorrhoeae (PPNG) occurring in the population served by the West Midlands Regional Health Authority were surveyed. Isolates that were subjected to plasmid analysis were found to be mainly the "Asian" type in travellers from abroad and their immediate contacts, whereas isolates apparently indigenous in origin were mainly "African" type. The emerging sigmoid curve of yearly incidence, which is apparent for both the country and the region, may indicate that a dynamic equilibrium is being approached in the susceptible core populations. The importance of vigorous contact tracing is underlined by the contrast between the incidence of PPNG strains in the United Kingdom and the larger numbers found in areas where they are hyperendemic and where contact tracing is ineffectual or non-existent.

\section{Introduction}

No reports have yet been published on the pattern of plasmids and auxotypes in penicillinase producing strains of Neisseria gonorrhoeae (PPNG) in the United Kingdom as a whole. Newly introduced cases come mainly from Asia and Africa in roughly equal proportions, however, with a smaller contribution from Europe and the rest of the world. ${ }^{1}$ Strains containing the 4.4 megadalton (Mdal) "Asian" plasmid are commonplace in parts of Africa, but, despite rare exceptions, ${ }^{2}$ it is still reasonable to assume that introductions from Asia are, in fact, "Asian" in type. It might therefore be expected that neither major type would predominate in the overall picture, although noticeable temporal and regional variation could still occur.

Soon after the emergence of PPNG strains, the 24.5 Mdal transfer plasmid was detected in combination with the Asian plasmid and also in a small proportion of non-PPNG strains. It was later reported in combination with the African plasmid, and this type now predominates in the Netherlands. ${ }^{2}$ Auxotyping permits further subclassification of strains and is useful in analysing changing patterns in local outbreaks of gonorrhoea, as well as providing additional evidence of the chain of spread where

Address for reprints: Dr J C Clay, Consultant Venereologist, Special Clinic Ward 19, The General Hospital, Steelhouse Lane, Birmingham B4 6NH

Accepted for publication 14 December 1984 traditional methods of contact tracing have failed or provided partial information short of proof.

The West Midlands Regional Committee on Genitourinary Medicine therefore decided to establish a framework for recording details of all past and future cases of infection caused by PPNG strains, to take full advantage of the information provided by the reference laboratories.

\section{Patients and methods}

A preliminary questionnaire sought information on 144 patients (95 men, 49 women) infected with PPNG strains and on their immediate and remote sexual contacts. The details gathered were: clinic No, sex, age, nationality or ethnic group, history of gonorrhoea, details of sexual contact(s), sites of infection and complications, plasmids, auxotypes, and serovars, details of treatment, and (for women) methods of contraception and parity.

The control group was originally collected at the height of the outbreak of gonorrhoea in Birmingham. It consisted of all 191 patients (115 men, 76 women) seen in that clinic during September 1982 who had a diagnosis of gonorrhoea (excluding that caused by PPNG strains) that was confirmed by cultures. This population sample was reasonably representative of patients seen in the centres that provided most of the patients in the survey who had gonorrhoea caused by PPNG strains, but more relevant sampling techniques will be required in future. 
For the purpose of analysis, indigenous infections (in 91 patients) were defined as those without detectable direct or remote links with travellers from abroad. Imported infections, those acquired abroad, were found in 42 patients and their immediate sexual contacts (there being no documented cases of tertiary spread). The remaining 11 patients had infections of unknown origin, the ultimate source of which was in doubt, such as in one patient whose sexual contacts had been exclusively with other British holidaymakers abroad.

Plasmid identification and auxotyping were undertaken by Drs N A Johnston, (Whitechapel, London) and A E Jephcott (Bristol) using standard methods. Not all strains were submitted for typing, some lost the plasmid on subculture, and others perished in the subculture chain. Nevertheless, sufficient numbers were typed to provide useful information.

\section{Results}

GENERAL PICTURE

Figure 1 and table I show that most patients infected with PPNG strains were seen in the clinics at Birmingham, Wolverhampton, Dudley, and Walsall. Almost all attended a clinic appropriate to their normal place of residence. These four centres lie in the heart of the West Midlands and form an almost continuous built up area. Indigenous infections were

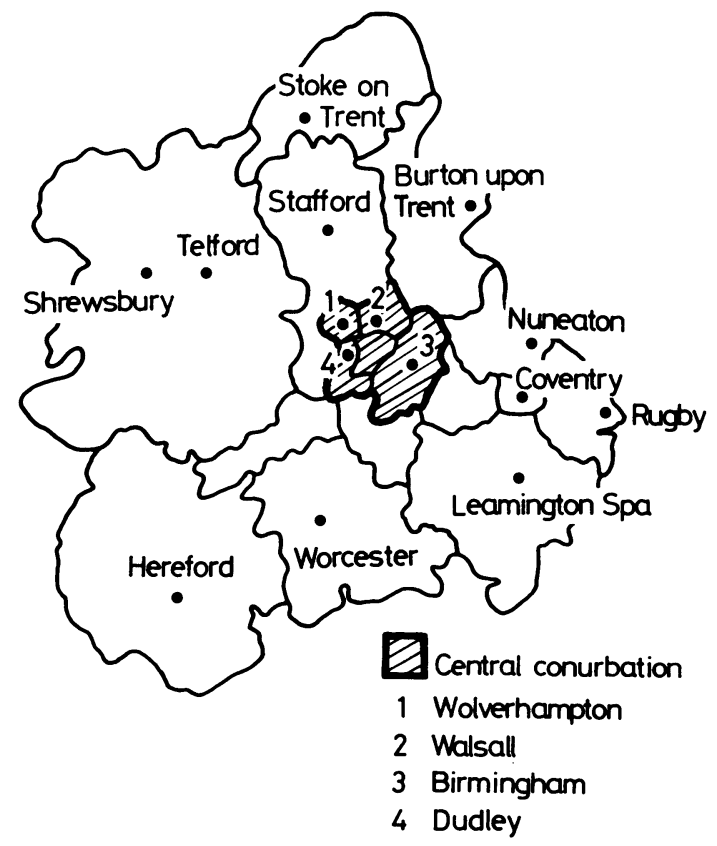

FIG 1 Map of West Midlands showing distribution of clinics. more prominent in clinics in these centres, whereas imported cases predominated in the more peripheral centres, except Coventry.

TABLE I Distribution of patients in the West Midlands infected with penicillinase producing strains of Neisseria gonorrhoeae (PPNG)

\begin{tabular}{lccrr}
\hline & \multicolumn{3}{c}{ No whose infections were: } \\
\cline { 2 - 4 } Clinic & Indigenous & $\begin{array}{l}\text { Uncertain } \\
\text { in origin }\end{array}$ & Imported & Total \\
\hline Central area: & & & & \\
$\quad$ Birmingham & 56 & 4 & 23 & 83 \\
Wolverhampton & 15 & 4 & 1 & 20 \\
$\quad$ Dudley & 9 & 1 & 3 & 13 \\
$\quad$ Walsall & 6 & 2 & 1 & 9 \\
Subtotal & 86 & 11 & 28 & 125 \\
Peripheral area: & & & & \\
$\quad$ Stoke & 1 & & 5 & 6 \\
Coventry & 3 & & 1 & 4 \\
$\quad$ Burton & 1 & & 3 & 3 \\
$\quad$ Worcester & & & 2 & 2 \\
$\quad$ Hereford & & & 1 & 1 \\
$\quad$ Shrewsbury & 5 & 11 & 42 & 14 \\
Subtotal & 91 & & 14 & 19 \\
Total & & & & \\
\hline
\end{tabular}

No cases were reported from Stafford, Telford, Rugby, Leamington, or Nuneaton.

Table II shows the emergence of indigenous strains in 1981, their progress to dominance in 1982 , and their spread to the more peripheral centres as time went by. As expected with such small numbers, the usual seasonal variation was only imperfectly mirrored. The coming of winter, however, was a valuable ally in control, and this has remained true for the first quarter of 1984 .

Figure 2 shows that the yearly incidence of cases of gonorrhoea caused by PPNG strains, both in the

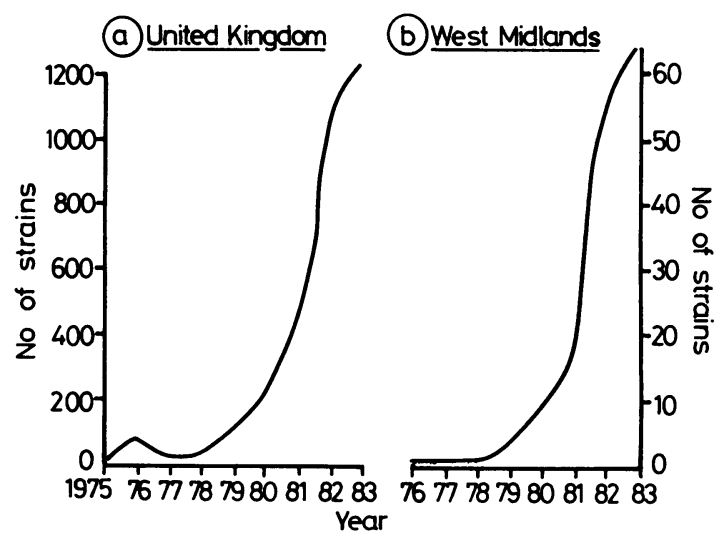

FIG 2 Yearly incidence of penicillinase producing strains of Neisseria gonorrhoeae (PPNG) in (a) the United Kingdom and (b) the West Midlands. 
TABLE II Quarterly incidence of infections with penicillinase producing Neisseria gonorrhoeae (PPNG)

\begin{tabular}{|c|c|c|c|c|c|}
\hline \multirow[b]{2}{*}{$\begin{array}{l}\text { Years and } \\
\text { quarters }\end{array}$} & \multicolumn{3}{|c|}{ No of patients whose infections were: } & \multirow[b]{2}{*}{$\begin{array}{l}\text { Total } \\
(n=144)\end{array}$} & \multirow[b]{2}{*}{$\begin{array}{l}\text { Centres with } \\
\text { indigenous cases }\end{array}$} \\
\hline & $\begin{array}{l}\text { Indigenous } \\
(n=91)\end{array}$ & $\begin{array}{l}\text { Uncertain } \\
\text { in origin } \\
(n=I I)\end{array}$ & $\begin{array}{l}\text { Imported } \\
(n=42)\end{array}$ & & \\
\hline $\begin{array}{r}1979 \begin{array}{r}1 \\
2 \\
3\end{array}\end{array}$ & & & 1 & 1 & \\
\hline 4 & & 1 & 1 & 2 & \\
\hline $\begin{array}{r}19801 \\
2 \\
3 \\
4\end{array}$ & & & $\begin{array}{l}1 \\
4 \\
2 \\
1\end{array}$ & $\begin{array}{l}1 \\
4 \\
2 \\
1\end{array}$ & \\
\hline $\begin{array}{rl}1981 & 1 \\
2 \\
3 \\
4\end{array}$ & $\begin{array}{l}2 \\
5 \\
1\end{array}$ & & $\begin{array}{l}4 \\
3 \\
1\end{array}$ & $\begin{array}{l}4 \\
5 \\
5 \\
2\end{array}$ & $\begin{array}{l}\text { Wo } \\
\text { Wo, } \\
\quad \text { Bi }\end{array}$ \\
\hline 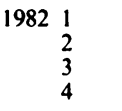 & $\begin{array}{r}1 \\
9 \\
23 \\
7\end{array}$ & 2 & $\begin{array}{l}2 \\
3 \\
2 \\
4\end{array}$ & $\begin{array}{r}3 \\
12 \\
27 \\
11\end{array}$ & $\begin{array}{l}\text { Bi } \\
\text { Wo, } \mathrm{Bi}, \mathrm{Wa}, \mathrm{D} \\
\mathrm{Bi}, \mathrm{Wa}, \mathrm{D} \\
\mathrm{Bi},\end{array}$ \\
\hline $1983 \begin{array}{r}1 \\
2 \\
3 \\
4\end{array}$ & $\begin{array}{r}11 \\
16 \\
8 \\
8\end{array}$ & $\begin{array}{l}5 \\
3\end{array}$ & $\begin{array}{l}2 \\
3 \\
5 \\
3\end{array}$ & $\begin{array}{l}13 \\
24 \\
16 \\
11\end{array}$ & $\begin{array}{l}\text { Wo, Bi, Wa, D, C* } \\
\text { Wo, Bi, Wa } \\
\text { Bi, Wa, D } \\
\text { Bi, } \quad \text { D, Bu* }\end{array}$ \\
\hline
\end{tabular}

Quarters: 1 = January to March, 2 = April to June, 3 = July to September, 4 = October to December.

Wo $=$ Wolverhampton; $\mathrm{Bi}=$ Birmingham; $\mathrm{Wa}=$ Walsall; $\mathrm{D}=$ Dudley; $\mathrm{S}=$ Stoke; $\mathrm{C}=$ Coventry; $\mathrm{Bu}=$ Burton.

*Indicates peripheral area.

United Kingdom ${ }^{13-6}$ and in the West Midlands, are beginning to describe sigmoid curves. This implies that the susceptible population currently affected is approaching a dynamic equilibrium point, although it hardly needs to be stated that other populations remain at risk. The fact that a thorough regional survey has produced this pattern supports the idea that the slowing national rate of rise is not a reporting artefact.

\section{DEMOGRAPHIC DATA}

Tables III and IV show the demographic data of the men and women studied. The patients with infections of uncertain origins were not included in the statistical analysis because of the small numbers in the group and the heterogenous nature of such a category. For ease of display, $95 \%$ probability limits have been taken throughout, although higher levels were recorded in some categories.

As was expected, with some exceptions, the demographic data of patients infected with indigenous strains strongly resembled those of the controls. The proportion of patients living apart from their spouses was significantly greater in those with indigenous infections but not significantly greater in those with imported infections than in the controls, but we strongly suspect that this is the type of artefact that appears in a retrospective survey of groups that have been studied with differing degrees of intensity. Similarly, we have omitted completely the figures on
TABLE III Demographic data of 95 men infected with penicillinase producing Neisseria gonorrhoeae (PPNG) strains and 115 with non-PPNG strains

\begin{tabular}{|c|c|c|c|c|}
\hline & \multicolumn{2}{|c|}{$\begin{array}{l}\text { No (\%) whose } \\
\text { infections were: }\end{array}$} & \multirow[b]{2}{*}{$\begin{array}{l}\text { Conirols } \\
(n=115)\end{array}$} & \multirow{2}{*}{$\begin{array}{l}\text { No whose } \\
\text { infections } \\
\text { were } \\
\text { uncertain } \\
\text { in origin } \\
(n=8)\end{array}$} \\
\hline & $\begin{array}{l}\text { Indigenous } \\
(n=55)\end{array}$ & $\begin{array}{l}\text { Imported } \\
(n=32)\end{array}$ & & \\
\hline $\begin{array}{l}\text { Single } \\
\text { Married } \\
\text { Separated }\end{array}$ & $\begin{array}{r}41 / 53(77) \\
4 / 53(8) \\
8 / 53(15)\end{array}$ & $\begin{array}{c}18 / 32(56)^{*} \\
10 / 32(31) \dagger \\
4 / 32(13)\end{array}$ & $\begin{array}{l}93 / 115(81) \\
18 / 115(16) \\
4 / 115 \quad(3) \neq\end{array}$ & $\begin{array}{l}4 / 8 \\
3 / 8 \\
1 / 8\end{array}$ \\
\hline $\begin{array}{l}\text { European } \\
\text { Black } \\
\text { Other }\end{array}$ & $\begin{array}{c}15 / 55(27) \S \\
34 / 55(62) \\
6 / 55(11)\end{array}$ & $\begin{array}{c}24 / 32(75) \S \\
2 / 32(6) \dagger \\
6 / 32(19)^{*}\end{array}$ & $\begin{array}{c}52 / 115(45) \S \\
57 / 115(50) \\
6 / 115(5)\end{array}$ & $\begin{array}{l}4 / 8 \\
4 / 8 \\
0\end{array}$ \\
\hline $\begin{array}{l}\text { Aged } \leqslant 25 \\
\text { White collar } \\
\text { worker } \\
\text { History of } \\
\text { gonorrhoea }\end{array}$ & $\begin{array}{l}30 / 53(57) \\
13 / 55(24) \\
25 / 53(47)\end{array}$ & $\begin{array}{c}6 / 32(19) \dagger \\
26 / 32(81) \dagger \\
6 / 31(19) \|\end{array}$ & $\begin{array}{l}71 / 115(62) \\
37 / 115(32) \\
42 / 115(37)\end{array}$ & $\begin{array}{l}1 / 8 \\
4 / 8 \\
7 / 7\end{array}$ \\
\hline
\end{tabular}

$\mathrm{p} \leqslant 0.05$ for: *imported infections $v$ controls; timported $v$ indigenous infections or controls; $\neq$ indigenous infections 1 controls; $\S$ all three $v$ each other; $\|$ imported $v$ indigenous infections.

multiplicity of contacts because the intensity of tracing was very different in those infected with PPNG and non-PPNG strains. The group of patients with indigenous infections contained many "repeaters" as well as some known prostitutes, pimps, and prison inmates. Many described themselves as unemployed, and we strongly suspected that the combination of pimps of Caribbean origin and white prostitutes was a more 
TABLE IV Demographic data of 49 women infected with penicillinase producing Neisseria gonorrhoeae (PPNG) strains and 76 with non-PPNG strains

\begin{tabular}{|c|c|c|c|c|c|}
\hline \multirow[b]{3}{*}{$\begin{array}{l}\text { Single } \\
\text { Married } \\
\text { Separated }\end{array}$} & \multicolumn{3}{|c|}{$\begin{array}{l}\text { No }(\%) \text { whose } \\
\text { infections were: }\end{array}$} & \multirow[b]{2}{*}{$\begin{array}{l}\text { Controls } \\
(n=76)\end{array}$} & \multirow{2}{*}{$\begin{array}{l}\text { No whose } \\
\text { infections } \\
\text { were } \\
\text { uncertain } \\
\text { in origin } \\
(n=3)\end{array}$} \\
\hline & \multirow{2}{*}{$\begin{array}{l}\begin{array}{l}\text { Indigenous } \\
(n=36)\end{array} \\
30 / 36(83) \\
3 / 36 \quad \begin{array}{l}(8) \\
3 / 36 \quad(8)\end{array}\end{array}$} & \multicolumn{2}{|c|}{$\begin{array}{l}\text { Imported } \\
(n=10)\end{array}$} & & \\
\hline & & $\begin{array}{l}4 / 9 \\
5 / 9 \\
0\end{array}$ & $\begin{array}{l}(44)^{*} \\
(56)^{*}\end{array}$ & $\begin{array}{r}62 / 76(82) \\
9 / 76(12) \\
5 / 76 \quad(7)\end{array}$ & $\begin{array}{l}2 / 3 \\
1 / 3 \\
0\end{array}$ \\
\hline $\begin{array}{l}\text { European } \\
\text { Black } \\
\text { Other }\end{array}$ & $\begin{array}{r}27 / 36(75) \\
6 / 36(17) \\
3 / 36 \quad(8)\end{array}$ & $\begin{array}{l}6 / 10 \\
2 / 10 \\
2 / 10\end{array}$ & $\begin{array}{l}(60) \\
(20) \\
(20)\end{array}$ & $\begin{array}{r}53 / 76 \quad(70) \\
21 / 76 \quad(28) \\
2 / 76 \quad(3)\end{array}$ & $\begin{array}{l}3 / 3 \\
0 \\
0\end{array}$ \\
\hline \multirow{3}{*}{$\begin{array}{l}\text { Aged } \leqslant 20 \\
\text { White collar } \\
\text { worker } \\
\text { Non-white } \\
\text { collar worker } \\
\text { Housewife } \\
\text { History of } \\
\text { gonorrhoea }\end{array}$} & $19 / 36(53)$ & $0 / 8$ & $*$ & $39 / 76(51)$ & $1 / 3$ \\
\hline & $\begin{array}{c}5 / 36(14) \dagger \\
26 / 36(72) \\
5 / 36(14)\end{array}$ & $\begin{array}{l}3 / 8 \\
1 / 8 \\
4 / 8\end{array}$ & $\begin{array}{l}(38) \\
(13) \ddagger \\
(50) \S\end{array}$ & $\begin{array}{l}26 / 76(34) \\
39 / 76(51) \\
11 / 76(14)\end{array}$ & $\begin{array}{l}2 / 3 \\
1 / 3\end{array}$ \\
\hline & $15 / 36(42)$ & $1 / 8$ & (13) & $17 / 76(22)$ & $1 / 3$ \\
\hline
\end{tabular}

$\mathrm{p}<0.05$ for: *imported $v$ indigenous or control infections; tindigenous $v$ control; fimported $v$ indigenous; §imported $v$ control infections.

prominent part of the picture than was admitted to us. The sigmoid curve of incidence mentioned previously supports the idea that there is such an infected core population. The demographic data of patients with imported infections differ considerably from those of patients with indigenous infections, and of controls. The international travellers were older and consequently more likely to be married. Many trips abroad were undertaken for business, and this was reflected in the greater proportion of men in the study population and in the occupations of both sexes. None of the local population of Caribbean descent gave a history of travel abroad, and the Negroes in this group were students from Africa. A history of gonorrhoea was less common in patients with imported infections than in controls.

\section{CLINICAL AND ASSOCIATED FEATURES}

Isolation rates from the urethra $(\mathbf{7 5 \%})$, cervix $(90 \%)$, and anorectum (38\%) in 32 women (data not shown) were similar to published results for non-PPNG strains. Infection of only the rectum occurred in one patient, who may well have harboured the organism for over a year. Evidently PPNG strains have no difficulty in maintaining themselves in the female rectum, so the small numbers of homosexuals affected in this (three) and other communities may show relatively little crossover of organisms between homosexual and heterosexual societies.

Pharyngeal cultures were taken only when indicated by a patient's history, and positive results represent $16 \%$ (seven) of the 45 patients on whom any information about the site of infection was available (data not shown). This was far more than the $3.5 \%$ isolation rate obtained in Birmingham in the past, when routine throat swabs were taken on all women who attended (Clay $J$, unpublished observation) and it may reflect a difference in lifestyle.

To calculate complication rates (data not shown) we considered only men with urethral infections and only non-pregnant women with uteruses. The relevant complications in the equation were taken to be conjunctivitis (in one patient), periurethral abscess (one), or epididymo-orchitis (three) in men; or acute salpingitis (seven), Bartholin's abscess (three), postpartum metritis with perihepatitis (one), or perianal abscess (one) in women. The complication rate for men was $5 \%$ and for women $26 \%$. Increased complications as a result of delays in diagnosis and treatment were documented only in men, but were thought to be likely in women.

The difference in contraceptive practices and the incidence of presumably unplanned pregnancy was interesting (table V). Patients with indigenous infections had better organised current contraceptive practices than controls, but more of the single women in the former group had been pregnant at least once. Prostitutes in this region, as in many others, are in the habit of asking their clients to use sheaths and, although this information is not included in the table, the practice has probably played a vital role in limiting the spread of infection.

TABLE V Contraception and unplanned pregnancy in 49 women infected with penicillinase producing Neisseria gonorrhoeae (PPNG) strains and 76 infected with nonPPNG strains

\begin{tabular}{|c|c|c|c|c|c|c|c|c|}
\hline \multirow[b]{2}{*}{$\begin{array}{l}\text { Method of } \\
\text { contraception }\end{array}$} & \multicolumn{6}{|c|}{ No $(\%)$ whose infections were: } & \multirow{2}{*}{\multicolumn{2}{|c|}{$\begin{array}{l}\text { No }(\%) \text { of } \\
\text { controls } \\
(n=76)\end{array}$}} \\
\hline & $\underset{l n}{I n d}$ & $\begin{array}{l}\text { genvus } \\
36)\end{array}$ & & $\begin{array}{l}\text { ported } \\
=101\end{array}$ & & $\begin{array}{l}\text { ncertain } \\
\text { origin } \\
=31\end{array}$ & & \\
\hline $\begin{array}{l}\text { Pill } \\
\text { None } \\
\text { IUCD } \\
\text { Sheath } \\
\text { Othert }\end{array}$ & $\begin{array}{r}16 \\
7 \\
6 \\
3 \\
4\end{array}$ & $\begin{array}{l}(44) \\
(20)^{*} \\
(16) \\
(8) \\
(11)\end{array}$ & $\begin{array}{l}4 \\
2 \\
1 \\
3\end{array}$ & $\begin{array}{l}(40) \\
(20) \\
(10) \\
(30)\end{array}$ & $\begin{array}{l}1 \\
1\end{array}$ & $\begin{array}{l}(33) \\
(33)\end{array}$ & $\begin{array}{r}32 \\
33 \\
8\end{array}$ & $\begin{array}{l}(42) \\
(43)^{*} \\
(11) \\
(4)\end{array}$ \\
\hline $\begin{array}{l}\text { Unmarried, } \\
\text { previously } \\
\text { pregnant }\end{array}$ & $20 / 3$ & $0(67)^{* * *}$ & & $4(25)$ & $1 / 2$ & $2(50)$ & $26 / 6$ & $2(42)^{* *}$ \\
\hline
\end{tabular}

${ }^{*} p \leqslant 0 \cdot 01 ; * * p \leqslant 0 \cdot 05$.

IUCD = intrauterine contraceptive device.

tunknown (3), hysterectomy (1), female sterilisation (1), male sterilisation (1), post partum (1), pregnant (3), rhythm method (1).

PLASMIDS AND AUXOTYPES

Table VI shows the plasmids of the strains isolated from all 144 patients with gonorrhoea caused by PPNG strains. Travellers from the West Midlands favour the Far East, and this was reflected in the predominantly "Asian" type strains isolated from 
TABLE VI Plasmids of 144 penicillinase producing strains of Neisseria gonorrhoeae

\begin{tabular}{|c|c|c|c|c|c|c|c|c|}
\hline & Untyped & Lost & African - & African + & Asian - & Asian + & $\begin{array}{l}\text { African - (Whitechapel) } \\
\text { Asian - (Bristol) }\end{array}$ & Total \\
\hline \multicolumn{9}{|l|}{ Imported strains from: } \\
\hline Far East & 18 & 2 & & & 1 & 6 & & 27 \\
\hline Middle East & 3 & & & & & 1 & & 4 \\
\hline Africa & 4 & & 1 & & 1 & 1 & & 7 \\
\hline Europe & 3 & & 1 & & & & & 4 \\
\hline Subtotal & 28 & 2 & 2 & & $2^{*}$ & $8^{*}$ & & 42 \\
\hline \multicolumn{9}{|l|}{ Strains of uncertain origin } \\
\hline Far East & & 1 & & & & & & 1 \\
\hline Africa & & & 2 & & & & & 2 \\
\hline Europe & 5 & & 3 & & & & & 8 \\
\hline Subtotal & 5 & 1 & 5 & & & & & 11 \\
\hline Indigenous strains from: & & & & & & & & \\
\hline West Midlands only & 11 & 1 & 27 & & 1 & & 4 & 44 \\
\hline London & 7 & 2 & $12+$ & 1 & 3 & & & 25 \\
\hline Rest of United Kingdom & 11 & & 10 & & 1 & & & 22 \\
\hline Subtotal & 29 & 3 & $49^{*}$ & $1^{*}$ & 5 & & 4 & 91 \\
\hline Total & 62 & 6 & 56 & 1 & 7 & 8 & 4 & 144 \\
\hline
\end{tabular}

$=$ without 24.5 megadalton transfer plasmid, $+=$ with transfer plasmid.

${ }^{*} p<0.001$ (imported Asian 38\% v African 8\%; indigenous African 59\% v Asian 5\%) 1982-3.

†One other contact in the rest of the United Kingdom.

these patients. In contrast, most of our indigenous strains have been "African" in type, which lends support to the concept of two forms of transmission occurring in the West Midlands. Conflicting reports on people linked by contact tracing, or from different reporting laboratories on one person, may well indicate multiple strains concentrated in the core population. This was supported by the isolation of two serovars from one prostitute in these patients.

Auxotyping has only recently been made available to us, and table VII shows the auxotypes of the 144 PPNG strains. Six contact pairs and one string of three contacts had identical auxotypes. A prototrophic Asian strain without transfer plasmid detected in a pair with imported infections was later found in an apparently unlinked patient with indigenous infection. Arginine and proline requirement was found in one pair of patients, of which the man was identified as carrying an African strain without transfer plasmid; the woman had an Asian strain without transfer plasmid identified by one laboratory and an African strain without transfer plasmid identified by the other. Another pair of patients had a prototrophic African strain without transfer plasmid in one partner and a proline requiring Asian strain without transfer plasmid in the other, both detected by the same laboratory. The main strain circulating in May to July 1983 was an arginine requiring African type without transfer plasmid, which suggested a link between infections that were apparently acquired in the West Midlands, others that may have come from other parts of the United Kingdom, and infections whose origin was uncertain but that centred on a widely travelled prostitute who had visited Europe and several parts of the United Kingdom.

TABI.E VII Auxotypes related to plasmids in 144 penicillinase producing strains of Neisseria gonorrhoeae

\begin{tabular}{|c|c|c|c|c|c|c|}
\hline \multirow[b]{2}{*}{ Auxotypes } & \multicolumn{6}{|l|}{ Plasmids } \\
\hline & $\begin{array}{l}\text { Untyped } \\
\text { /lost }\end{array}$ & African & African + & Asian - & Asian + & $\begin{array}{l}\text { African - (Whitechapel) } \\
\text { Asian - (Bristol) }\end{array}$ \\
\hline Untyped & 58 & 46 & 0 & 4 & 5 & $3^{*}$ \\
\hline $\mathrm{Arg}^{-}$ & 8 & 8 & 1 & 0 & 0 & 0 \\
\hline Pro $^{-}$ & 2 & 0 & 0 & 2 & 1 & 0 \\
\hline Arg ${ }^{-}$Pro $^{-}$ & 0 & 1 & 0 & 0 & 0 & 1 \\
\hline Prototrophic & 0 & $i$ & 0 & 3 & 0 & 0 \\
\hline Total & 68 & 56 & 1 & 9 & 6 & 4 \\
\hline
\end{tabular}

- = without 24.5 megadalton transfer plasmid, $+=$ with transfer plasmid.

*One with WI and WII serotypes, and two with WII serotype.

$\mathrm{Arg}^{-}=$arginine requiring, Pro- ${ }^{-}=$proline requiring. 
CONTACT TRACING AND CONTROL OF GONORRHOEA

The medical profession made a mixed contribution to control. Gonorrhoea is rare in the context of experience of urogenital complaints in women presenting in general practice, and considerable skill is required in selecting patients for full diagnostic tests. In contrast, the likelihood of urethral discharge in men being sexually transmitted should make full investigation mandatory in all cases. Before attendance at a clinic, seven women were diagnosed correctly, and one woman and eight men were treated without investigation. Table VIII shows the results of contact tracing expressed conventionally in relation to each patient diagnosed, without regard to the fact that this method of reporting overstates the case. The final arbiter of contact tracing efficiency is success in control, and the contrast between control in this country and in hyperendemic areas supports the vital importance of contact tracing.

\section{Treatment}

All patients who have acquired their infections in hyperendemic areas should ideally be treated with an agent active against PPNG strains, and this policy is now standard throughout the West Midlands. Nevertheless, 12 patients infected in the Far East and Africa and many infected locally were initially treated with penicillins in our clinics.

Table IX shows the results of treatment with various antibiotics. Spectinomycin is the only one for which we have figures adequate for comment, and the cure rate appears to be good. Since the end of 1983, however, we have seen the emergence of strains resistant to spectinomycin (shown by the disc sensitivity method) in a classic "ping pong" infection pattern. This drug should therefore possibly be reserved for use in travellers from hyperendemic areas, who in the West Midlands appear to be least likely to cause tertiary spread.

\section{Conclusions}

The term indigenous is used as a working definition to cover infections with PPNG strains whose origins
TABLE IX Results of treatment with various antibiotics of assessable cases of uncomplicated gonorrhoea

\begin{tabular}{lccc}
\hline Drug & $\begin{array}{c}\text { No (\%) cured at } \\
\text { first follow up }\end{array}$ & $\begin{array}{l}\text { No (\%) cured at } \\
\text { second follow up }\end{array}$ \\
\hline Penicillins & $7 / 64$ & $(11)$ & $2 / 59$ \\
Spectinomycin & $53 / 56$ & $(95)$ & $35 / 38^{*}(92)$ \\
Cephalosporins & $11 / 13$ & $8 / 10^{*}$ \\
Co-trimoxazole & $5 / 8$ & $4 / 7$ \\
Kanamycin & $6 / 6$ & $4 / 7$ \\
Acrosoxacin & $2 / 2$ & $1 / 1$ \\
Tetracyclines & $1 / 3$ & $1 / 3$ \\
\hline
\end{tabular}

*One pharyngeal infection not cured in each 'group.

have not been traced to travellers from abroad. Inevitably the category will include some patients who are secondary contacts of patients infected with imported strains; and, although a working definition is obviously useful, it is important to understand philisophically what the true definition might be. The outbreak of gonorrhoea in Liverpool lasted several months, and was almost certainly caused by a single introduced strain that had spread for several generations. As control was successfully achieved, these infections have not generally been regarded as truly indigenous. The pattern in the West Midlands has been, as far as one can be certain, a collection of small, often overlapping, outbreaks that have been controlled successfully. Introductions into the region from other parts of the United Kingdom have been mainly from London, which is not only the principal focus for imported strains, but may also be the site of true sustained endemic spread. The use of plasmid analysis and auxotyping will permit us to observe, particularly in the case of unusual strains, the spread of infection in the West Midlands. As most infections with gonorrhoea in general are acquired locally, and some strains possibly survive preferentially in, for example, multiply infected patients or homosexuals, a truly uniform pattern is likely never to occur. Even so, the uniform distribution of some strains would provide firm evidence of sustained endemic spread in a given population.

The West Midlands Regional Committee on Genitourinary Medicine intends to continue this

TABLE VIII Results of contact tracing for 258 patients

No whose infections were:

\begin{tabular}{|c|c|c|c|}
\hline \multirow[b]{2}{*}{ Diagnoses of contacts } & \\
\hline & Indigenous & Uncertain in origin & Imported \\
\hline $\begin{array}{l}\text { Gonorrhoea caused by PPNG strains } \\
\text { Gonorrhoea caused by other gonococci } \\
\text { Treated gonorrhoea* } \\
\text { Non-specific urethritis } \\
\text { Tests for gonorrhoea negative }\end{array}$ & $\begin{array}{r}64 \\
13 \\
4 \\
4 \\
12\end{array}$ & $\begin{array}{r}12 \\
1\end{array}$ & $\begin{array}{r}10 \\
1 \\
1\end{array}$ \\
\hline Total No (\%) of contacts traced/index cases & $97 / 167(58) \dagger$ & $15 / 30(50)$ & $12 / 61(20)$ \\
\hline
\end{tabular}

* Patient seen or doctor contacted and history strongly indicative of gonorrhoea.

tIncluding a 6 week old baby who was contact of mother. 
study with certain principal objectives: (1) to observe the outward spread from the major conurbation and its relation to the establishment of individual strains in the core population; (2) to document the presence of multiple strains in individual patients; (3) to explore and define any subcultural links with the capital city; (4) to develop criteria for the temporary blanket use of alternative antibiotics in controlling infection in a defined population; and (5) to evaluate alternative antibiotics in poorly documented topics, such as pharyngeal infection.

I thank Drs A K Biswas, D F Morris, C Romer, R A Sparks, D L Sugrue, A A H Wade, T M Wanas, and their clinic staff for cooperating on this project, and $\mathrm{Dr} V$ Manoharan for help in examining contact tracing records.

\section{References}

1. Public Health Laboratory Service Communicable Disease Surveillance Centre and Communicable Diseases (Scotland) Unit. Penicillinase-producing gonococci in Britain, 1983. $\mathrm{Br}$ Med J 1984; 288: 1746 .

2. Ansink-Schipper MC, van Klingeren B, Huikeshoven $\mathbf{M H}$, Woudstra RK, Dessens-Kroon M, van Wijngaarden LJ. Epidemiology of PPNG infections in the Netherlands: analysis by auxanographic typing and plasmid identification. British Journal of Venereal Diseases 1984;60:141-6.

3. McCutchan JA, Adler MW, Berrie JRH. Penicillinaseproducing Neisseria gonorrhoeae in Great Britain, 1977-81: alarming increase in incidence and recent development of endemic transmission. Br Med J 1982;285: 337-40.

4. Arya OP, Rees E, Percival A, Alergant CD, Annels EH, Turner GC. Epidemiology and treatment of gonorrhoea caused by penicillinase-producing strains in Liverpool. British Journal of Venereal Diseases 1978;54:28-35.

5. Phillips I. $\beta$-lactamase-producing, penicillin-resistant gonococcus. Lancet 1976; ii:656-7.

6. Wilkinson $A E$, Seth $A D$, Rodin $P$. Infection with penicillinaseproducing gonococcus. Br Med J 1976; ii: 1233. 